\title{
SECULARIZATION \\ IN THE MIND OF MUSLIM REFORMISTS A Case Study of Nurcholish Madjid and Fouad Zakaria
}

\author{
Mun'im Sirry* \\ The University of Chicago, Illinois, USA
}

\begin{abstract}
Nurcholish Madjid (Indonesia) and Fouad Zakaria (Egypt) represent the two most influential Muslim thinkers concerned with the issue of secularization. This article is a comparative analysis of their ideas, which have triggered intellectual debate on the term "secularization" and its implications in the Muslim world over the last three decades. Positing the discourse on secularization and secularism as a means to confront the obscurantist Islamist tide, both scholars use it as a starting point to discuss important issues in the context of their respective countries about the necessity to reform the current social, political, cultural, and intellectual stagnancy. They differ, however, in perceiving the extent of the discourse of secularism. Using the term "secularization" very carefully, Madjid makes clear that it should not be understood as leading to secularism in Indonesia. Unlike Madjid, Zakaria, inheriting the secularism debate from his predecessors, is more oriented toward rescuing secularism before it totally disappears in Egypt.
\end{abstract}

Keywords: Secularization, secularism, Muslim reformists, modernity, Islamism.

\section{Introduction}

Nurcholish Madjid (Indonesia) and Fouad Zakaria (Egypt) can be said as two most influential Muslim thinkers who seriously engage in the intellectual debate on secularization issue in the Muslim world. In

\footnotetext{
* I wish to thank Michael Sells, Malika Zeghal (Chicago), M. Sani Umar, James Rush (ASU), Leonard Binder, Michael Morony, Ismail Poonawala (UCLA), Micheal Feener (National University of Singapore), Robert Hefner (Boston University), and Nader Hashemi (Northwestern) for the invaluable advice and discussions.
} 
the last three decades the idea of secularization launched by Madjid and Zakaria has not only triggered the intellectual debate on the term "secularization" and its implication in the Muslim world, but also unveiled the most complicated issue pertaining to the question as to whether or not Islam is compatible with modernity. Since then the debates on secularization issue took the form of newspaper articles and books, but there also were some widely noted public debates between the proponents and opponents of secularism. Madjid himself first launched his provoking idea of secularization in the widely attended public discussion held in January 1970 at the Islamic Research Center, in Menteng Raya, Jakarta. The debate between Zakaria representing secularist camp and Yust\$al-Qara $\$$ ind Muhłmmad al-Ghaza\$> representing Islamist camp took place in July 1986 in the Cairo headquarters of the Doctors' Union. These debates revolve around the questions: Can Islam be compatible with secularism? Can it be integrated into modernity? To what extent can Islam be contextualized and reinterpreted in order to make it in harmony with liberty?

To most Western scholars, this may engender two different reactions. On the one hand, many Western scholars would say that secularization is a global phenomenon which sweeps all religions of the world. In Western literature on the phenomenon of secularization, it is not an uncommon thesis that the process of secularization, once it has taken root in the West, will inevitably spread like an oil spill all across the globe. ${ }^{1}$ According to this thesis, the non-Western religions will also be affected by the process of secularization. Islam is no exception. ${ }^{2}$ Even since the first penetration of Western culture, the world of Islam has been prone to an ever-spreading process of secularization. On the other hand, alterations have also taken place in the way of thinking in the West in the past twenty years or so that it is no longer taken for granted, as it was in the past, that secularization is to be viewed as an inevitable process, almost as an escapable fate which was to spread across the entire face of the globe. ${ }^{3}$ Moreover, many scholars argue for

\footnotetext{
1 This tenet is one of the underlying ideas of A. Th. van Leeuwen, Christianity in World History (Edinburgh: University of Edinburgh Press, 1964).

2 D.C. Mulder, "Secularization in the Muslim World," in D.C. Mulder (ed.), Secularization in Global Perspective (Amsterdam: VU Boekhandel, 1981), p. 25.

3 Peter Berger, for instance, says: "If the experience of transcendence is indeed ineradicable in human life, then it will sooner or later reassert itself on the level of legitimations.... In that case, secularization is neither progressive nor irreversible." See
} 
the exceptionalism of Islam. The British anthropologist Ernest Gellner, for instance, says:

It is possible to disagree about the extent, homogeneity, or irreversibility of this trend [secularization]...; but, by and large, it would seem reasonable to say that it is real. But there is one very real, dramatic and conspicuous exception to all of this: Islam. To say that secularization prevails in Islam is not only contentious. It is simply false. Islam is as strong as it was a century ago. In some ways, it is properly stronger. ${ }^{4}$

It is hard to accept Gellner's conclusion that there has not been any change in the strength of Islam, as if Islam has not changed since the time of the Prophet. On the contrary, we have witnessed that a variety of Islamic discourses have mushroomed in the contemporary Muslim world. The Muslims' debate on secularization issue, as I will argue in this paper, is not merely aimed at following the path of the Western conception of secularization which continues to be used, often in a taken-for-granted fashion, to explain the religion-and-society relationship, ${ }^{5}$ but mainly intended as a catalyst to discuss more crucial issues pertaining to any effort at reforming or refreshing Muslim understanding of Islam. I would argue that it is from Muslims' debates on secularization that the most radical and innovative Islamic thought can be found, to the extent that these debates touch upon the very core issue facing the modern Muslim world. In order to shed light on the secularism debate in contemporary Islamic thought, especially in the last three decades, I will focus my analysis on the ideas of the leading Indonesian thinker Nurcholish Madjid and Egyptian thinker Fouad Zakaria. In the first part, I will identify major issues raised by both Madjid and Zakaria which eventually generate fruitful, and yet often fierce, discussions among those who oppose and support them. In the second part, I will discuss the socio-political context in which they launch their progressive ideas and how they affect and even shape the discourse on the relationship between state and religion in their respective countries. The reason for selecting Madjid and Zakaria is

Peter L. Berger, Against the World for the World: The Hartford Appeal and the Future of American Religion (New York: Seabury Press, 1976), p. 12.

${ }^{4}$ Ernest Gellner, Postmodernism, Reason and Religion (London: Routledge, 1992), p. 5.

5 See, for instance, David Lyon, "Rethinking Secularization: Retrospect and Prospect," Review of Religious Research, 26/3 (March 1985), pp. 228-43. 
not only because their ideas of secularization and secularism are more elaborate than any other Muslim thinkers, but also because they represent the two most productive Muslim countries in terms of the intellectual debates on Islam and secularism.

\section{Nurcholish Madjid: A Brief Intellectual Biography}

Just one day after Nurcholish Madjid died on August 29, 2005, at the age of 66, three Indonesian Muslim scholars wrote in the daily English newspaper The Jakarta Post that "It is simply impossible for someone to discuss contemporary Indonesian Islam, or perhaps even Indonesia in general, without mentioning Madjid." I think it is not an exaggeration for nearly three decades scholars have been writing books and dissertations on his ideas and practices. His own articles and essays collected in several books received remarkable responses. Cak Nur, Madjid is popularly called, is one of the country's most influential thinkers who have been lauded internationally since the 1970s. A wide range of labels have been attached to him: Secularist, reformist, neomodernist, nationalist, moderate, pluralist, liberal, and most recently the nation's "great teacher (guru bangsa)."

Madjid was born in 1939 in a small town of Jombang, East Java. He received his secondary education at Pesantren Darus Salam in Gontor, Ponorogo, known for its discipline and good language training, both in Arabic and English. He pursued his first academic degree at the Institute of Islamic Studies, IAIN Syarif Hidayatulah in Jakarta, where he graduated in 1968. As a student, Madjid was active in the Association of Muslim Students (Himpunan Mahasiswa Islam) - a modernist, urban Muslim student organization, known as HMI - and held the very prestigious position of General Chairman during two periods: 1966-1969 and 1969-1971.7 It was within the HMI that Madjid was able to articulate his intellectual orientations and the fact that he is the only individual who has led HMI for two consecutive periods has undoubtedly also served to give additional weights to his views and

\footnotetext{
${ }^{6}$ Fachry Ali, Bahtiar Effendy, and Ichsan Ali-Fauzi, "Nurcholish Madjid, for Islam and Indonesia," The Jakarta Post, August 30, 2005.

7 Karel Steenbrink notes: "Several predecessors and successors of Madjid as General Chairman of the HMI became minister of the Indonesian Republic. See Karel Steenbrink, "Nurcholish Madjid and Inclusive Islamic Faith in Indonesia," in Ge Speelman, Jan van Lin and Dick Mulder (eds), Muslims and Christians in Europe: Breaking New Ground (Uigeverif Kok - Kampen, 1993), pp. 28-43.
} 
statements. ${ }^{8}$ During this period at the HMI Madjid launched a number of provoking ideas, the most important of which can be summarized under the slogan of secularization. ${ }^{9}$

In the late 1970s he went to the United States to pursue this graduate studies in Chicago with Fazlur Rahman, a Pakistani-born scholar who decided to reside in the U.S. as his life was threatened in his own country. Madjid completed his Ph.D. in 1984 with a dissertation on the theological thought of Ibn Taymiyya, especially on the relation between reason and revelation. Upon his return to Indonesia, Madjid founded Paramadina Foundation (Yayasan Paramadina) as an intellectual think-tank where he and other scholars might freely engage in very productive discussions. In the early 1990s, Madjid extended his activities as to establish Paramadina as one of the prestigious university in Jakarta. Now Paramadina has a building of its own, a regular office, and a good series of publication.

Twenty years later since he held an important speech on secularization issue in the early 1970s, The Jakarta Cultural Center of Taman Ismail Marzuki (TIM) invited him to present a stocktaking of "20 years of Renewal of Islamic Thinking" on October 21, 1992. At that time Madjid did not present an inventory or history of the debate, but tackled some old and new problems in his own way. The title of his paper was "Some Reflections about Religious Life for the Next Generation", which again evoked a long and hot debate. Some of his adverse opponents, including Abdul Qadir Djaelani, were surprised at the fact the spirit of Madjid's reform movement never tends to become overcast, but continues to flame. ${ }^{10}$ Madjid's books and articles continue to generate public debates, but at the same time become more influential. His publications include: Cita-cita Politik Islam Era Reformasi [Islamic Political Ideals in the Reformation Era]; ${ }^{11}$ Dialog Keterbukaan: Artikulasi Nilai Islam

[Open Dialogue: Islam in Contemporary Socio-Political Discourse]; ${ }^{12}$

\footnotetext{
${ }^{8}$ Bahtiar Effendy, Islam and the State in Indonesia (Singapore: Institute of Southeast Asian Studies, 2003), p. 71.

9 Steenbrink, "Nurcholish Madjid and Inclusive," p. 30.

10 See Abdul Qadir Djaelani, Menelusuri Kekeliruan Pembaharuan Pemikiran Islam Nurcholish Madjid (Bandung: Yadia, 1994).

${ }^{11}$ Nurcholish Madjid, Cita-cita Politik Islam Era Reformasi (Jakarta: Paramadina, 1999).

12 Nurcholish Madjid, Dialog Keterbukaan: Artikulasi Nilai Islam dalam Wacana Sosial Politik Kontemporer (Jakarta: Paramadina, 1998).
} 
Islam Agama Kemanusiaan [Islam as Religion of Humanity]; ${ }^{13}$ Islam Agama Peradaban [Islam as Religion of Civilization];14 Pintu-pintu menuju Tuhan [Ways toward God];15 Islam, Kerakyatan, dan Keindonesiaan [Islam, Citizenship and Indonesia];16 Islam: Doktrin dan Peradaban [Islam: Doctrine and Civilization]:;17 Islam, Kemodernan, dan Keindonesiaan [Islam, Modernity, and Indonesianness]; ${ }^{18}$ and others.

\section{Secularization and the Realization of God's Vicegerent}

The turning point that made Madjid controversial was his electrifying speech to a gathering of four Islamic organizations on January 2, 1970, in Jakarta. In his paper on "Keharusan Pembaharuan Pemikiran Islam dan Masalah Integrasi Ummat (The Necessity of Renewal of Islamic Thought and the Problem of Integration of the Islamic community)," he offered the straightforward observation that Indonesian Muslims suffered stagnation in religious thinking and had lost the "psychological striking force" in their struggle. ${ }^{19}$ The speech marked a watershed in his career as for the time in the contemporary Indonesian Islam it offered an amalgam of theological, political, sociological and hermeneutical analysis.

Central to his thesis is a critique that vast majority of Muslims were unable to differentiate values that are transcendental from those which are temporal. In fact, he pointed out further that the hierarchy of values was often the reverse; transcendental values were conceived as temporal and vice versa. Everything was likely to be perceived as transcendental, and therefore, without exception, valued as divine. ${ }^{20}$ As a result of this mode of religiosity, "Islam is [viewed as] equal in value as tradition; and becoming Islamic is comparable to becoming traditionalist." 21 It is in this context that he called for secularization "to make what was temporal stay temporal and liberate the Muslim

\footnotetext{
13 Nurcholish Madjid, Islam Agama Kemanusiaan (Jakarta: Yayasan Wakaf Paramadina, 1995).

${ }^{14}$ Nurcholish Madjid, Islam Agama Peradaban (Jakarta: Paramadina, 1995).

${ }_{15}$ Nurcholish Madjid, Pintu-pintu menuju Tuhan (Jakarta: Paramadina, 1994).

${ }^{16}$ Nurcholish Madjid, Islam, Kerakyatan, dan Keindonesiaan (Bandung: Mizan, 1993).

${ }^{17}$ Nurcholish Madjid, Islam: Doktrin dan Peradaban (Jakarta: Paramadina, 1992).

18 Nurcholish Madjid, Islam, Kemodernan, dan Keindonesiaan (Bandung: Mizan, 1987).

19 Ibid., pp. 204-14.

${ }^{20}$ Effendy, Islam and the State, p. 71.

${ }^{21}$ Madjid, Islam, Kemodernan, dan Keindonesiaan, p. 207.
} 
community from the tendency to spiritualize it." 22 Therefore, the Muslims should always examine and reexamine the truth of any value in the face of material, moral, and historical facts.

As Robert W. Hefner pointed out, Madjid's effort at "secularization" is necessitated by the most central of Muslim doctrines, tawhis belief in the uncompromised oneness of God. ${ }^{23}$ Madjid argues that secularization is also intended to strengthen human functions as "God's vicegerent on earth." These functions give Men ample room of freedom to choose and determine themselves the ways and methods of improving their life on earth as well as call them to become responsible for their actions to God. ${ }^{24}$ Therefore, it is safe to say, as Fachry Ali and Bahtiar Effendy argue, that Madjid's fundamental viewpoints derived from his radical understanding of two basic principles in Islam: (1) the concept of tawhiloneness of God); and the notion of humans are the vicegerents of God (khaliat al-Allas fi $>a l$-'ard)\} From these two principles he formulated his theological premises which suggest that only Allah possesses absolute transcendency and divinity. As a consequence to their acceptance of this monotheistic principle, quite naturally Muslims should perceive the world and its temporal affairs (social, cultural, or political) as they are. Viewing the world and its objects in a sacred or transcendental manner can be theologically considered to be contradictory to the very notion of Islamic monotheism. ${ }^{25}$ For sacralization of things other than God is, indeed, shirk (polytheism), as opposed to tawhis Madjid argued that the concrete meaning of secularization is desacralization of anything other than the transcendental, namely this worldly affair. ${ }^{26}$

According to Madjid, an Islamic reform is only possible provided that Muslims are prepared to undertake a path of renewal. To undergo such religious renewal, he suggested that Muslims liberate themselves from the tendency to transcend values which are supposedly profane

\footnotetext{
22 Ibid.

${ }^{23}$ Robert W. Hefner, Civil Islam: Muslims and Democratization in Indonesia (Princeton and Oxford: Princeton University Press, 2000), p. 117.

24 Ibid.

${ }_{25}$ Fachry Ali and Bahtiar Effendy, Merambah Jalan Baru Islam: Rekonstruksi Pemikiran Islam Orde Baru (Bandung, Mizan, 1986), p. 130; See also Effendy, Islam and the State, p. 72.

${ }^{26}$ Madjid, Islam, Kemodernan, dan Keindonesiaan, p. 208.
} 
into the domain of divinity. As a consequence of the belief that Islam is timeless and universal, there is an inherent obligation for Muslims to initiate creative thinking relevant to the demands of the modern age. This endeavor can only be realized if Muslims enjoy some degree of confidence to allow any ideas, however unconventional they may be, to be expressed and communicated freely. More importantly, given the fact that Islam conceives human beings as naturally oriented towards truthfulness, Muslims need to be open-minded. Furthermore, they should accept and absorb any ideas, regardless of their origins, provided they objectively speak of truth. "[It is] hard to understand that Muslims nowadays become more closed and narrow-minded, whereas their Holy Book commends that they should listen to ideas and follow the best of them," said Madjid. ${ }^{27}$

Finally, Madjid concluded that in order to reformulate and put forward new progressive ideas we need groups of "liberal" thinkers, who are neither traditionalists nor sectarians. This idea is based on his observation that many Indonesian Muslim organizations, which were previously known as the agents of reform, have stopped as reformers. They were unable to grasp the spirit of the reformation idea itself, that is, the idea of progress. He hoped that young Muslim generations would be willing and ready to carry out the task of reforming the Islamic thinking. ${ }^{28}$

Since then Madjid was known as the "locomotive of reform movement" and his progressive thought has always been referred to as "the movement of reform thinking (gerakan pembaharuan pemikiran)." 29 Undoubtedly his idea of the renewal of Islamic thought triggered a widespread controversy within the Indonesian Muslim community. The reactions took the form of discussion, speech, Friday sermon, and newspaper articles. Those who supported Madjid would say that Madjid's idea was a proper "shock therapy" in order to wake up the Muslim community from an intellectual stagnancy and backwardness because of their failure to respond creatively to socio-political developments. To his opponents, Madjid's idea of the renewal of

\footnotetext{
${ }^{27}$ Ibid., p. 211.

28 M. Syafi'i Anwar, Pemikiran dan Aksi Islam Indonesia: Sebuah Kajian Politik tentang Cendekiawan Muslim Orde Baru (Jakarta: Paramadina, 1995), p. 54.

${ }_{29}$ Pardoyo, Sekularisasi dalam Polemike (Jakarta: Pustaka Utama Grafiti, 1993), p. 91; Ali and Effendy, Merambah Jalan Baru, pp. 122-34.
} 
thought was too far away from the theological doctrine and authoritative sources of Islam. The use of certain terms like "secularization," "liberalization," “intellectual freedom," "idea of progress," and so forth were considered too vulgar and devaluating the Islamic doctrines. From political perspective, they further argue, Madjid's reform agenda could bring about a disintegration or conflict within the Indonesian Muslim community. ${ }^{30}$

\section{Secularization versus Secularism}

As far as his main thesis is concerned, he concluded in response to such reactions that not much resistance was given to the essence of his idea, and most of the reactions and resistance were concerned with the problem of terminology, especially the use of the word "secularization." 31 He made it clear that he interpreted this idea along the lines of Harvey Cox in his well known best-seller The Secular City: Secularization and Urbanization in Theological Perspective. ${ }^{32}$ In this work, Cox defines secularization as "the liberation of man from religious and metaphysical tutelage, the turning of his attention away from other worlds and toward this one." 33 Yet, he maintains that secularization is different from secularism. In his words:

In any case, secularization as a descriptive term has a wide and inclusive significance. It appears in many different guises, depending on the religious and political history of the area concerned. But whatever it appears, it should be carefully distinguished from secularism. Secularization implies a historical process, almost certainly irreversible, in

\footnotetext{
30 Among those who supported him were: M. Dawam Rahardjo, Djohan Effendi, Utomo Danadjaja, Eky Syachruddin, Usep Fathuddin, and others; while his opponents included: Endang Saefuddin Anshari, Ismail Hasan Metarium, Abdul Qadir Djaelani, HM Rasyidi, and others. For a more detailed discussion on this, see Ali and Effendy, Merambah Jalan Baru, pp. 134-43; Anwar, Pemikiran dan Aksi, pp. 54-99.

${ }^{31}$ Nurcholish Madjid, "Beberapa Catatan sekitar Masalah Pembaruan Pemikiran dalam Islam" in his Islam, Kemodernan, dan Keindonesiaan (Bandung, Mizan, 1987), pp. 215-20.

32 This book was first published in 1965 by The MacMillan Company, New York, and soon drew a public attention and widespread controversy among theologians, sociologists of religion and others. Within a short time The Secular City had gone into multiple printings. One year later after its publication, the same publisher published a collection of reaction papers to this book entitled The Secular City Debate, ed. by Daniel Callahan (New York: The MacMillan Company, 1966).

${ }^{33}$ Harvey Cox, The Secular City (New York: The MacMillan Company, 1965), p. 15.
} 
which society and culture are delivered from tutelage to religious control and closed metaphysical world views. We have argued that it is basically a liberating development. Secularism, on the other hand, is the name of an ideology, a new closed world view which functions very much like a new religion. ${ }^{34}$

The above passage was also quoted by Madjid in his paper to indicate that it was the notion of "liberating development" as well as the "clear distinction between secularization and secularism" which he employed in articulating his ideas concerning the logical consequences of Islamic monotheism (tawhi As he put it in his paper:

Secularization is not meant as the implementation of secularism, because secularism is the name of an ideology, a new closed world view which functions very much like a religion. In this case, what is meant [by secularization] is every form of liberating development... [nor is it] to convert Muslim to become secularists. Rather, it is meant to temporize worldly values, and to liberate [Muslims] from the tendency of making those values transcendental.

With this statement, he not only provided an explanation of what he meant by secularization, but at the same time he also defended and reconfirmed his caution of using what his opponents called as "Western category."

The term "secularization" was meant as a necessary process that would enable the Islamic community to distinguish between transcendental and temporal values. For Madjid, "secularization", understood as a process of liberating development, is also a conditio sine qua non to facilitate Muslims -in accordance with their function as vicegerents of God (khalif al-Allaßfi $>$ al-'ard) $\}$ in their endeavors to relate the universalism of Islam to today's Indonesia. ${ }^{35}$ If secularization is a dynamic process, it is not the case with secularism. Secularism is a worldly ideology. It constitutes a philosophy and new worldview which

\footnotetext{
${ }^{34}$ Cox, The Secular City, p. 18.

35 This notion of "secularization" can also be found in Madjid's four other articles, written during 1970-73. These include: "Beberapa Catatan sekitar Masalah Pembaharuan Pemikiran dalam Islam," "Sekali Lagi tentang Sekularisasi," "Perspektif Pembaharuan Pemikiran Islam," and "Menyegarkan Paham Keagamaan di Kalangan Umat Islam Indonesia." All these essays are included in his Islam, Kemodernan, dan Keindonesiaan, pp. 215-56.
} 
is in contradiction with almost all world religions. ${ }^{36}$ Therefore, he concluded, "although we strongly encourage the process of secularization [to take place in our religion and life], but we also strongly refuse secularism." 37

Nonetheless, the controversies and polemics about his use of the term "secularization" did not last. Since the 1980s, following his return from the University of Chicago where he obtained his $\mathrm{PhD}$ under the guidance of a prominent Pakistani Muslim thinker of the neomodernist stream, Fazlur Rahman, Madjid was able to provide more convincing arguments. Although he has remained faithful to the substance of his renewal ideas, considering the controversy of the term he used, he sometimes suggested to rephrase the term "secularization" as "radical devaluation" or "desacralization." Thanks to the indirect intellectual encouragement of similar understanding of "secularization", as promulgated by a number of prominent and influential sociologists, such as Talcott Parsons ${ }^{38}$ and -more importantly- Robert N. Bellah, ${ }^{39}$ he has been able to pinpoint the main difference between him and his opponents, namely in perspectives. While his opponents, especially HM Rasjidi, understood secularization from philosophical point of view, he viewed secularization from sociological perspective. ${ }^{40}$

From sociological perspective, as Parsons indicates, secularization reveals the liberation of society from superstition, and not as the elimi-

\footnotetext{
36 A brief and yet insightful discussion on Madjid's view on "secularization" versus "secularism" can be found in Hefner, Civil Islam, pp. 116-119.

${ }^{37}$ Nurcholish Madjid, "Beberapa Catatan sekitar Masalah Pembaruan Pemikiran dalam Islam," in his Islam, Kemoderan, dan Keindonesiaan, p. 218.

38 See Talcott Parsons, Edward Shils, Kaspar D. Naegelle, and Jesse R. Pitts (eds), Theories of Society: Foundations of Modern Sociological Theory (New York: Free Press, 1961), pp. 249-51; 256-63.

39 See his "Islamic Traditions and the Problems of Modernization," in Beyond Belief: Essays on Religion in a Post-Traditionalist World (Berkeley and Los Angeles: University of California Press, 1991), pp. 146-67.

40 See Madjid, "Sekularisasi Ditinjau Kembali", in his Islam, Kemodernan, dan Keindonesiaan, pp. 257-60. In fact, this article is a footnote of his paper entitled "Sekitar Usaha Membangkitkan Etos Intelektualisme Islam di Indonesia" contributed in honor to 70 years of Rasjidi. See Endang Basri Ananda (ed.), 70 Tabun Prof. Dr. Rasjidi (Jakarta: Harian Pelita, 1985).
} 
nation of religious orientation of social norms and values..$^{41}$ Moreover, the liberation process could take place as a logical consequence of a certain religious orientation, especially monotheism. Robert Bellah calls this type of secularization as "radical devaluation, one might legitimately say secularization, of all existing social structures in the face of this central God-man relationship. This meant above all the removal of kinship, which had been the chief locus of the sacred in pre-Islamic Arabia, from its central significance." 42 So, the use of the word "secularization" in sociology could mean liberation, i.e. liberation from spiritualizing temporal things. It also means "desacralization" to the extent that the sacrality of certain things which are not sacral should be avoided. ${ }^{43}$

The implication of such theological pronouncements, in Madjid's view, are that there is nothing sacred about matters of an Islamic state, Islamic political parties, or an Islamic ideology. Accordingly, Muslims again primarily because of the logical consequences of their adherence to the principles of tawhi - should be able to "secularize" or "desacralize" their perceptions on those worldly issues. In the light of this, he introduced the phrase: "Islam Yes, Partai Islam No" (Islam Yes, Islamic Party No). ${ }^{44}$ With this jargon, among other things, he encouraged his fellow Muslims to direct their commitment to Islamic values and not to institutions, even those of Islamic origin such as Islamic parties..$^{45}$

\section{Fouad Zakaria: A Brief Intellectual Biography}

In contrast to many Egyptian Muslim thinkers who used to hold secularist views but now subscribe to political Islam, Fouad Zakaria is consistently defending the fate of secularism in the face of the increasing strength of political Islam in Egypt. During the 1980s when secularism was under siege and severe attack from the Islamist camp, Zakaria stood up and spoke on behalf of open secularism at a public

\footnotetext{
${ }^{41}$ In this context, Madjid referred to Parsons' paper published on book in Parsons, Shils, Naegelle, and Pitts (eds), Theories of Society: Foundation of Modern.

42 See Robert N. Bellah, Beyond Belief (New York: Harper \& Row Publishers, 1970), p. 151.

43 Madjid, "Sekularisasi Ditinjau Kembali,” p. 259.

${ }^{44}$ Madjid, "Keharusan Pembaruan Pemikiran Islam dan Masalah Integrasi Umat," in his Islam, Kemodernan, dan Keindonesiaan, p. 204.

${ }^{45}$ Effendy, Islam and the State, p. 75.
} 
panel with prominent Islamist thinkers - the first public occasion in decades at which secularism was treated seriously as an issue. ${ }^{46} \mathrm{He}$ was quite brave to defend secularist views confronting such respected ulama $>$ (Muslim scholars) as Yuser $\gg$ al-Qara Ghazal $>$ in front of unfriendly audience. As Nancy E. Gallagher described the event, during Zakaria's talk, the audience had been increasingly restless. Each point he made was greeted with rumbling and threatening protest. The moderator continually called for silence and kept asking the highly partisan audience to show respect to the speakers. ${ }^{47}$

However, we know a very little about this "leading secular Arab philosopher", 48 although prominent "ulama $>$ like al-Qara $\$$ - $>$ i $>$ feels necessary to write a book devoted to rebut Zakaria's idea of secularism, entitled al-Islam wa al-'Imanimb Wajhan li Wajhin: Radd 'Ilmi > ala $\$$ onad Zakaria wa Jama al-Tlman (Islam and Secularism Face to Face: Scientific Refutation of Fouad Zakaria and his Fellow Secularists). ${ }^{49}$ One of his opponents, Muhłmmad Ibrałim Mabruk, says that "apart from our intellectual differences, we acknowledge that Fouad Zakaria is one of the most prominent Arab thinkers in the last quarter of the twentieth century because of his precision and consistency in his scientific endeavors to the extent that we should always consult his works." 50 Thanks to Ibra Abu $\Re$ a who translated into English one of Zakaria's important works, Myth and Reality in the Contemporary Islamist Movement (2005), ${ }^{51}$ in which Zakaria offers a sustained critique of the intellectual, political, and social

46 Alexander Flores, "Egypt: A New Secularism?," Middle East Report, no. 153 (JulyAugust 1988), p. 28.

47 Nancy E. Gallagher, "Islam vs. Secularism in Cairo: An Account of the Dar alHikma Debate," Middle East Studies, 25/2 (April 1989), pp. 108-215.

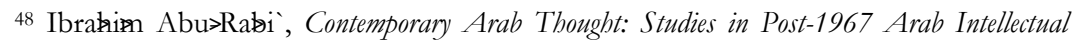
History (London and Virginia: Pluto Press, 2004), p. 97.

49 Yust\$al-Qara Zakaria wa Jama al-Ima (Cairo: Daßal-S\{hytrah, 1978).

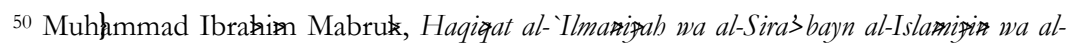
Ilmamal 2 (Cairo: Daßal-Tawzi $>$ wa al-Nashr al-Islamipah, 2000), p. 121.

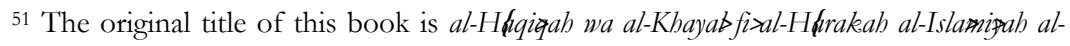
Mu a 
foundations and contemporary manifestations of Islamism in the Arab and Muslim world.

Zakaria was born in Port Said in Egypt in 1927.52 After graduating from high school in Cairo he went to the University of Cairo where he obtained a BA in philosophy in 1949. In 1952, he obtained an MA degree in philosophy from 'Ayn Shams University and in 1956 he received his $\mathrm{PhD}$ from the same university. Afterwards, Zakaria taught philosophy at 'Ayn Shams University until 1974. Between 1974 and 1991, he taught at the Department of Philosophy at Kuwait University. In 1998, his students and admirers at Kuwait University published a Festschrift in his honor. Currently, Zakaria lives in retirement in Cairo.

In his early publications, Zakaria published a great number of books on Western philosophy and rationalism in general, but later he paid much attention to the problem of religious revivalism. Here is a summary of his main publications: Nietzsche: Silsilah Nawa al-Fikr alGharbi Nietzsche: The Series of Western Genius Thinkers];53 Spinoza; ${ }^{54}$ A $>$ Vaqliyat fi lushkilat al-Fiker wa al-Thaqa) [Critical Considerations of Cultural and Intellectual Problems];55 Al-Tafki $\gg$ al-Tlmi $¥$ Scientific Thinking];5 Khitdzila - Aql al- Arabi Addressing Arab Reason];57 Al-

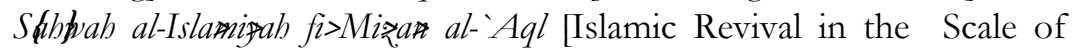
Reason];58 Al-Thaqa al-'Arabizarb wa 'Azmat al-Khalij $\ngtr$ Arab Culture and the Gulf Crisis]; ${ }^{59}$ and $A$ al-Falsafah [Horizons of Philosophy]. ${ }^{60}$

\section{Historical Necessity of Secularism}

Zakaria is not the first to introduce secularism into the Egyptian intellectual discursive vocabulary, because the debate on this issue had

\footnotetext{
52 This biography is heavily based on Abu $\mathbb{R}$ a $`$ 's account, which he concedes that this biography was provided by Zakaria himself to him in an interview in Cairo in January 2004.

${ }^{53}$ Fouad Zakaria, Nietssche: Silsilah Nawa al-Fikr al-Gharbi>(Cairo: Daßal-Ma a 1956).

${ }^{54}$ Fouad Zakaria, Spinoza (Cairo: Daæal-Nahdłh al-`Arabiæah, 1963).

55 Fouad Zakaria, A 'Aømah li al-Kita\$, 1975).

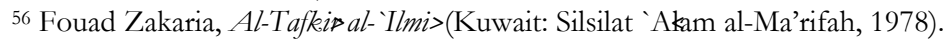

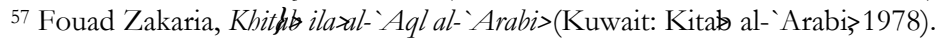

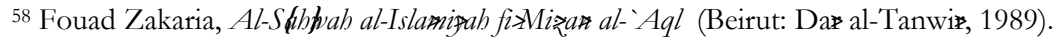

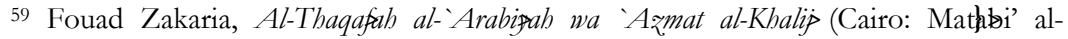
Ahiram, 1991).

${ }^{60}$ Fouad Zakaria, A al-Falsafah (Beirut: Daßal-Tanwiß,1988).
} 
taken place since the middle of the nineteenth century. ${ }^{61} \mathrm{He}$ inherits this perennial controversy from his predecessors who first encountered with European tangible cultural and intellectual impacts in the Arab region. At that point, secularism entered the intellectual debate in the Arab world. ${ }^{62}$ Perhaps, this can be traced back to early Muslim thinkers such as Rifa al-T\{h

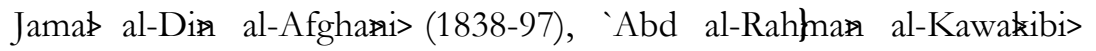
(1854-1902) and Muhłmmad 'Abduh (1949-1905). The next generations include disciples of 'Abduh, like Qasim Amiæ(1865-1908) and Ahthad Lut $>$ al-Sayyid (1872-1963), and culminated in 'Ali>Abd al-Raæiq (1888-1966), a graduate of al-Azhar and Oxford, who contributed to the debate with a book published in 1925 that turned to be one of the most controversial works in modern Islamic history: alIslar wa Usifsal-Hr\{km (Islam and the Foundation of Governance). ${ }^{63}$

I am not suggesting that there is nothing new with the contemporary debate on Islam and secularism. There has always been change and continuity, affirmation and revision, in the intellectual history of Islamic discourse. Unlike in the case of Madjid, the reactions to Zakaria do not merely revolve around the problem of terminology and illustration, but also the question as to whether secularism is a solution or problem for the Muslim world today. It is interesting to note the way in which the proponents and opponents of secularism in Egypt delve into the question of historical specificity versus universality to justify whether or not secularism is admissible in Islamic society. By historical specificity, I mean the tendency among the Islamists to limit secularism to the experience of West European and North American countries with Christianity. Secularism, they argue, was born in pre-modern Christian Europe out of the necessity to fight

\footnotetext{
${ }^{61}$ Azzam Tamimi, "The Origins of Arab Secularism," in John L. Esposito and Azzam Tamimi (eds). Islam and Secularism in the Middle East (New York: New York University Press, 2000), pp. 13-28.

${ }^{62}$ For a detail discussion on this, see Nazik Saba Yared, Secularism and the Arab World (1850-1939) (London: Saqi Books, 2002).

${ }^{63}$ In that famous and controversial work, Abd al-Raziq asserted that Islam was a religion and not a state, a message not a government, a spiritual edifice not a political institution, a proposition that led to his defrocking by the Azhar Community of 'Ulama $>$ For a good discussion on `Abd al-Raæiq's liberal idea and some responses to it, see Dr. Leonard Binder, Islamic Liberalism (Chicago: University of Chicago Press, 1988), especially chapter IV.
} 
the crippling dominance of the church over the political realm and over intellectual life. As Muhłmmad 'Imarah, who was once leftist now turns Islamist, put it:

If the European renaissance was linked to secularism, after its decline had been tied to the hegemony of religion and church over state and society... then the march of our Arab-Islamic civilization was exactly the opposite. For the Arab-Islamic renaissance was intimately linked to the hegemony of the Islamic shari $x_{\text {h }}$ over a state that was civilian and Islamic at the same time, while the deviation from the Islamic character of the law was the beginning of the path of our nation into inertia and decline. ${ }^{64}$

It is this claim of the specificity of the European experience that the secularists, such as Zakaria, have bluntly rejected. Let me quote the whole of his main arguments:

The thesis that Islam does not and did not know a religious institution at all is greatly exaggerated.... That religious authority existed throughout Islamic history. Sometimes it used its positions and influence for the defense of the true principles of religion, and that led to intense clashes with rulers, be they caliphs, sultans or princes. At other times, they put themselves at the disposal of the ruler and issued statements and fatwaßfor him, giving legal support for his behavior even if it was unjust or reckless....

[T] he conditions of medieval Christianity were not fundamentally different from the conditions prevailing in Islam. Of course, there are many details in which the two beliefs differ... but they shared the general feature of comprehensiveness, and thus one of the reasons justifying the emergence of secularism in Europe can also be advanced under the conditions prevailing in the Islamic world.... ${ }^{65}$

Zakaria further argues that "the reasons that pushed Europe in the direction of secularism are cropping up in our present Islamic world, and therefore the widespread idea that secularism is the result of specifically European conditions in a certain stage of its development

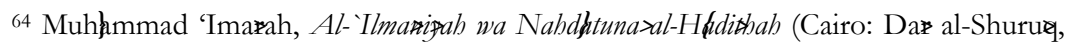
1987), p. 29.

${ }^{65}$ Fouad Zakaria, Al-Sablizah al-Isla p. 63.
} 
is baseless." ${ }_{66}$ There is an argument held by several Muslim thinkers that secularism was necessary for European progress, while the Muslim world did not suffer those conditions that made secularism inevitable in European societies. He regrets that this argument was quite attractive and appears decisive which places Muslims in an embarrassing position and makes a mockery of them. According to Zakaria, many writers seem to have taken this argument at face value, and here he does not mean Islamists such as al-Ghazal\$al-Qara $>$ a $>$; Anwa $\gg$ Jundi $>$ and 'Ima arh, but also others influenced by Western culture such as $\mathrm{H}\{\mathrm{ssa} \mathrm{H}\{$ nafi, $>$ Muhłmmad 'A Syaf al-Dawlah. ${ }^{67}$

In addition to advancing historical argument, Zakaria moves forward to challenge the Islamists' rhetorical or propagandist criticism of secularism. Most Islamists look upon secularism as a kind of kufr (unbelief) and irtida (apostasy). ${ }^{68}$ A leading Egyptian theologian Muhłmmad al-Ghazaß>issues a fatwa $>$ that whoever advocates secularism is an apostate from Islam. ${ }^{69}$ The first victim of this type of fatwa as Faraj Foda who was assassinated by two members of Islamic Jihad on June 8, 1992, for having been a secularist and an outspoken critic of Islamic organizations. The assassination of Foda took place a few months after he was involved in public debate with al-Ghazal the Cairo Book Fair in January 1992. ${ }^{70}$ Indeed, nowadays, Islamists have succeeded in equating secularism with atheism in the mind of public, using it as a slogan to intimidate their political adversaries, charging them with apostasy and unbelief, deserving the death punishment.

Zakaria acknowledges that this charge against secularism is the Islamists' strongest and most dangerous weapon. "When the secularist

\footnotetext{
${ }^{66}$ Zakaria, Al-S $\{$ buzah al-Islamizah, p. 66.

${ }^{67}$ Fouad Zakaria, Myth and Reality in the Contemporary Islamist Movement (London and Ann Arbor: Pluto Press, 2005), p. 33.

${ }^{68}$ Fauzi M. Najjar, "The Debate on Islam and Secularism in Egypt," Arab Studies Quarterly, 18/2 (Spring 1996), p. 2.

${ }^{69}$ See Muhłmmad Ibratim MabruR, Al-Nma al-Islamipah, 1990), p. 148.

70 Alexander Flores, "Secularism, Integralism and Political Islam: The Egyptian Debate", Middle East Report (July-August 1993), p. 34; Najjar, "The Debate on Islam and Secularism," p. 3.
} 
position is predefined as irreligious, the whole question is resolved before any debate takes place." 71 In this case, it does not matter whether the judgment passed by the Islamists is antithetical to both logic and history, since no one exerts any effort to think about accurately. What is more important is to distort the reputation of the secularists in the minds of people by manipulating the term "secularism." According to Zakaria, "it is true that some reject religion but certainly many other secularists are religious, and many religious people are secularist, since, in both cases, religion preserves its sacred character by being distinct from changing religious practices, while at the same time organizing important parts of human life, such as the ethical and spiritual." 72 Even the European secular movement, to Zakaria, was not a reaction against religion but against a method of thinking. Europeans were advancing in science and industrialization, and the biggest obstacle to these advances was the closed religious thinking of the church. ${ }^{73}$

Contrary to its critics, argues Zakaria, secularism is not the product of a particular society in a specific phase of its evolution, but it is a necessary requirement for any society threatened by the oppression of tyrannical and authoritarian modes of thinking, in which millions of people are subjected to a systematic campaign to rob them of their ability to question, criticize, and think about their future. Zakaria contends that the Islamists' confusion of the term clearly reflects the decline of Arab thought in the past two decades. An example of this decline is the fact that a large number of Arab people, including the Islamists, blindly embrace wrong ideas without first engaging in much contemplation or thought. ${ }^{74}$

\section{The Project of Arab Enlightenment}

$A b u \Re a ß x$ in his Introduction to Zakaria's work tries to posit the latter's idea of secularism within the current project of Arab enlightenment (tanwir $\rightarrow 55$ It is not without reason because since the last three decades the contemporary Arab enlightenment trend has been

\footnotetext{
${ }^{71}$ Zakaria, Myth and Reality, p. 24.

72 Ibid., p. 25.

73 See Gallagher, "Islam vs. Secularism in Cairo," p. 210.

${ }^{74}$ Zakaria, Myth and Reality, pp. 44-5.

${ }^{75}$ Ibra Abu $\Re$ a
} 
exhausted. Recently, however, we have witnessed the emergence of progressive groups that struggle to disseminate liberal and rational ideas and to revive Egypt's enlightenment tradition. Worthy of mention is Jam iyat al-Nida>al-Jadi (the New Appeal Society), established in late 1992, as a "platform for liberal thought." Its founders, mostly university professors, leading thinkers, businessmen and media persons, stress the need for disseminating and strengthening liberal values and ideas. They believe that Egypt had experienced a great liberal tradition, worthy of revival and development, and that enlightenment and conscious understanding of Islam and Arab culture would demonstrate that they are in harmony with liberty. Another important group is called Jam'izat al-Tanwi $\gg$ (Enlightenment Society), established in October 1992 by a group of Egyptian intellectuals. They also strive to revive Egypt's enlightenment tradition. ${ }^{76}$

How does Zakaria's idea of secularism fit to this project? We should keep in mind that most of these enlightenment groups emerged to counteract the rise of the Islamist tide in contemporary Egypt. As Zakaria admits, secularism presently is on the defensive in every sphere. That is to say, its major goal at present is to resist this torrential Islamist current. ${ }^{77}$ It is not an exaggeration to say, therefore, that Zakaria represents the most innovative and serious attempt to salvage the contemporary Arab liberal and enlightenment movement from its current historical impasse.

Having been on the defensive, Egyptian secularists and intellectuals have finally taken certain measures to counteract the Islamist tide. Convinced that the triumph of the Islamic movement would set Muslim society apart from the rest of the world, and out of date and out of touch with real life, Zakaria argues that Islam should be properly understood in order to be in harmony with the modern age. He takes a critical position vis-à-vis the applicability of the Qur'aæ and the viability of Islamic tradition in the modern era. A critical thinker, he says, must subject both the Qur'aæand tradition to strict historical criticism if he/she is to learn from them. ${ }^{78}$ Zakaria basically encourages the same methodology adopted by both Mohammad

\footnotetext{
${ }^{76}$ See Najjar, “The Debate on Islam and Secularism,” p. 3

77 Zakaria, Myth and Reality, p. 17.

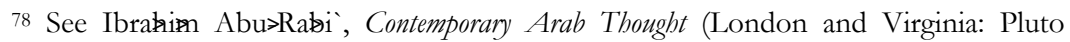
Press, 2004), p. 117.
} 
Arkoun and Nas\} $\mathrm{H}\{$ \{rid AbuZayd in the analysis of Islamic religious tradition. ${ }^{79}$

Seen from this point, we can understand that what is meant by secularism is not a carbon copy of Western secularism. There is something more important that he wanted us to grasp. That is, the rational project of enlightenment. To put this in words of Zakaria:

In reality, such values as rationality, criticism, logic, and mental independence are not unique to Western civilization, but are found in Islamic civilization as well. Contemporary secularists in the Muslim world need not be carbon copies of modern Western thinkers, but rather an extension of the rational tradition of the Mu'tazilites, alFarabi; $;$ bn Rushd, and Ibn al-Haytham. ${ }^{80}$

In other words, enlightenment is ingrained in the Islamic tradition. Hence, enlightenment means giving priority to reason in apprehending existence and the world. The Mu'tazilites, he says, were the first champions of reason in Islam. In modern times, the reformist Muhłmmad 'Abduh stressed that rational inquiry is one of the principles of Islam. ${ }^{81}$

However, Zakaria's contention that "secularism as an idea, as a movement, and as a worldview is a civilizational necessity (ddrurah badd $\rightarrow$ ab)," 82 is highly contested by the Islamists. The question would be: Is it possible to accept secularism without the political and social package associated with it? Probably Zakaria would answer "yes", since secularism, at least to his understanding, is nothing but a reflection of a specific discourse of thinking that must not be connected to the West and that secularism reflects a constant intellectual necessity on the part of any society trying to break from authoritarianism and move forward autonomous reason. ${ }^{83}$

\section{Socio-Political Context}

Although Madjid and Zakaria live in different social and political contexts, both use the discourse on secularization and secularism as a

\footnotetext{
${ }^{79}$ Ibid.

80 Zakaria, Myth and Reality, p. 41.

81 Ibid.

82 Abu $¥$ ały , Contemporary Arab Thought, pp. 122-3.

83 Zakaria, Myth and Reality, p. 41.
} 
starting point to discuss important issues about the necessity to reform the current social, political, cultural, and intellectual stagnancy. In other words, secularization is not a goal, but only a means to confront the obscurantist Islamic tide. By secularization, about which Madjid actually means desacralization, Madjid is able to take the idea of Islamic state off from political agenda in Indonesia. For Madjid, the term "secularization" is meant as a necessary process that would enable the Islamic community to distinguish between sacred and profane values, and the Islamists' conception of an Islamic party or Islamic state is far from being sacred or Islamic.

Zakaria is also facing the proliferation of Islamist trends in contemporary Egypt which forces progressive thinkers like him to challenge the Islamist basic argument for the implementation of shari the comprehensive nature of Islam (shamid). In his debate with al-Qara have to cover all aspects of life. "One could maintain respect for religion while leaving other activities for human endeavor." $84 \mathrm{He}$ mentions that there is overlapping of the human and the divine in the life of every human being. Human and natural law is partly derived from the customs and values of the people which include religious beliefs. Likewise, the sharith is based in part on local customs and values. He reminds the "Islamist camp" of the distinction they must draw between "textual Islam" and "historical Islam." He argues that implementing the shari falls in the domain of "historical Islam," and therefore, it needs "a careful and comprehensive re-examination in light of the fact that from the standpoints of science and reason, everything in the human arena is subject to change." 85

However, one would notice the different tone in which both Madjid and Zakaria used the terms "secularization" and "secularism" respectively. Madjid seems to be very careful in using the term "secularization" to the extent that he made clear that it should not be understood as to lead to secularism. He agreed with his critics that secularism is a closed ideology (suatu paham yang tertutup), an ideology that is denying the real life after this world. ${ }^{86} \mathrm{He}$ then cited the

\footnotetext{
${ }^{84}$ See Gallagher, "Islam vs. Secularism in Cairo," p. 210.

85 Zakaria, Myth and Reality, p. 9.

86 Nurcholish Madjid, "Sekularisasi Ditinjau Kembali," in his Islam, Kemodernan dan Keindonesiaan, p. 257.
} 
Qur'anic verses (surt al-Jatiyah: 24) to indicate that secularism is not compatible with religion, especially Islam..$^{87}$

One possible reason for this cautionary attitude is the fact that he was one of the first, if not the first, to introduce secularization issue into the Indonesian theological discursive tradition. ${ }^{88}$ Before the 1970s, there was not much, if any at all, discussion about the compatibility of Islam and secularization. There had been many discussions and polemics on modernization issue, but none of them was related to secularization. In 1968, two years prior to his speech, Madjid engaged in discussions with a number of Indonesia's "secular modernizing intellectuals" concerning the issue of modernization. In his view it appears that the underlying messages behind the rhetoric of modernization as promulgated by those intellectuals in the early period of the New Order regime were belittling - not to say anti- religious values. According to Madjid, some of them even depicted the calls to Islamic prayer using audio devices as "electronic terrors". In this debate he argued very strongly that modernization is not the emulation of Western cultural values. Rather, in his view, "modernization is rationalization, not Westernization." 89 As recorded by a Malaysian scholar Muhammad Kamal Hassan in his dissertation, this intellectual position earned him the title "the young Natsir (Natsir muda)". ${ }^{90}$ Although in the 1950s and 1960s many Western scholars believed that modernization would have resulted in the process of secularization, Madjid 1968's paper entitled "Modernization is Rationalization, not Westernization" did not allude even in passing to the secularization issue. Many scholars, including his close associate Ahmad Wahib,

\footnotetext{
${ }^{87}$ Madjid, "Sekularisasi Ditinjau Kembali," pp. 257-8.

88 I think Hefner is correct when he makes an insightful observation that "The influence of early New Order debates on Madjid's scholarship was also evidence in the fact that one of the first topics he chose to take from his discussion group out into the public arena concerned the thorny issue of secularization." See Hefner, Civil Islam, p. 116.

89 Madjid, "Modernisasi ialah Rasionalisasi bukan Westernisasi," in his Islam, Kemodernan, and Keindonesiaan, pp. 171-203.

${ }^{90}$ Muhammad Kamal Hassan, Muslim Intellectual Responses to "New Order" Modernization in Indonesia (Kuala Lumpur: Dewan Bahasa dan Pustaka Kementrian Pelajaran Malaysia, 1982).
} 
suggested that Madjid's visit to the United States in 1969 "changed his thoughts and views," an allegation of which Madjid had rejected. ${ }^{91}$

If we look at the notion of "secularization" that appeared in his five articles written during 1970-73, we find some interesting developments in Madjid's idea. As Kamal Hassan notes, Madjid's ideas before the 1970s represented the idea of "idealist Muslim" or simply a reformist, while after the 1970s he tended to be more "realistaccommodationist". 92 Madjid attempted to elaborate the Islamic thought in its relation with the modernization of socio-political attitude of contemporary Indonesian Islam. In other words, unlike his predecessors, such as Mohammad Natsir, Rasjidi, Deliar Noer, and others, Madjid's ideas seem to be more empirical. Of course, Madjid was aware of the fact that secularism has acquired "bad" connotation. In his 1970's paper that made him controversial, he has in the first place distinguished between secularization and secularism, by saying that "secularization is not meant as the application of secularism." He then attempted to give "new meaning" to the term "secularization" different from secularism commonly understood in the West. However, due to several criticisms, he made it clear that he used the term "secularization" not in its "anti-religious" tendency, but as "liberating development", by referring to the Harvard theologian Harvey Cox. It is difficult to ascertain whether Madjid at that period was aware of the fact that Coxian conception of secularization evoked a storm of comments and criticisms; because, in Cox's opinion, the decline of religion is irreversible in the "secular city". ${ }^{3}$ What is certain is that after he returned from the University of Chicago he no longer referred to Harvey Cox to justify the sociological meaning of secularization, but instead, he referred to the sociologists Talcott Parsons and Robert Bellah. Perhaps, he was by then aware of the controversy surrounding Cox's work, to the extent that it is impossible for him to avoid a controversy if the source from where he derived his

\footnotetext{
${ }^{91}$ Nurcholsih Madjid, "Sekapur Sirih," in Pardoyo, Sekularisasi dalam Polemik, p. xv. See also Anwar, Pemikiran dan Aksi, p. 47. Compare this to Hassan, Muslim Intellectual Responses, p. 118.

92 Hassan, Muslim Intellectual Responses, p. 89.

9320 years later after the publication of his The Secular City, Harvey Cox revised some of his previous ideas and he now believes that "religion returns to the secular city." See Harvey Cox, Religion in the Secular City: Toward a Postmodern Theology (New York: Simon and Schuster, 1984).
} 
idea of secularization is itself controversial. In an article he wrote in 1985, he said:

Although the sociological meaning of secularization has been widely used by social scientists, we still have to acknowledge that the controversy does not come to an end. That can be illustrated by the debate and controversy about Harvey Cox's The Secular City. The difficulty arises from the fact that the Enlightenment Age in Europe had produced the philosophy of secularism as an anti-religious ideology. ${ }^{94}$

For Madjid, it is more important to discuss the substance of the idea of Islamic reform than to make a fuss about terminology. In the aftermath of the controversy, as Hefner notes, "Madjid himself expressed misgivings at his choice of terms, commenting publicly that his reference to "secularization" had invited misinterpretation." 95 Madjid then concluded, "Therefore, considering the never-ending controversy of the terms "secular", "secularization", and "secularism", it is a wise not to use those terms, and instead we can use technical terms which are more acceptable and neutral." 96

Unlike Madjid, Zakaria is far from being the first to introduce the term "secularism" into the Egyptian intellectual discourse, rather he inherited the secularism debate from his predecessors. In Zakaria's time, as he himself admits, secularism is on defensive side, and he comes to rescue secularism before it totally disappears. Zakaria's anxiety is understandable, for since 1970s, which Geneive Abdo calls "the third wave of Islamic activism", the Islamists had been gaining considerable popularity. ${ }^{97}$ By 1981, they gained enough organizational strength to assassinate President Anwar Sadat. Unable to take over the government, some factions of the Islamist groups participated in the Parliamentary elections and now become members of Parliament. Perhaps, the strongest issue for the Islamists was the shari question on which their position were supported by broad sectors of the Egyptian people. ${ }^{98}$ It is in this context that Zakaria strongly contends

\footnotetext{
${ }^{94}$ Madjid, Islam, Kemodernan, dan Keindonesiaan, p. 260.

${ }^{95}$ Hefner, Civil Islam, p. 118.

${ }^{96}$ Madjid, Islam, Kemodernan, dan Keindonesiaan, p. 260.

97 Geneive Abdo, No God but God: Egypt and the Triumph of Islam (Oxford and New York: Oxford University Press, 2000), p. 7.

98 Barry Rubin, Islamic Fundamentalism in Egyptian Politics (New York: Palgrave MacMillan, 1990), p. 24.
} 
that in fact the Islamic movements have no a specific plan for society as a whole and that their concern is limited to the individual, as if the total of individuals makes up a society. ${ }^{99}$

That is why Zakaria seems to be very aggressive in his defense of secularism in order to encounter the current Islamist tide in Egypt. In his view, the Islamist ideal of an Islamic state undermines the very nature of civil society, and only secularism can safeguard the freedom and human rights. Secularists like Zakaria are convinced that Arab society contains the necessary seeds for secularization and modernization, and that what is needed is a proper implementation of secularist philosophy and worldview. 100

However, it is simply a mistake to group Zakaria into the extreme secularist camp (tatdruf ilmart) $>$ If we use the categorization made by William E. Shepard, Zakaria can be grouped as moderate. Shepard divides secularism into two categories: pure secularism and moderate secularism. The former is "any view that would openly follow an ideology other than Islam in most areas of public life," and the latter "seeks to separate religion from politics and other areas of public life."101 Muhłmmad 'Ima describes the moderate secularist: "They are believers in God as Creator of the universe, but non-believers in Him as an administrator and ruler of worldly affairs." 102 Zakaria is aware that some of his opponents have labeled him as an extreme secularist. He asserts that secularist authors like him are of course careful in the choice of their words to avoid "the accusations of unbelief that the ignorant uses to threaten any intellectual striving to bring a gleam of light into darkened minds.... One will discover that the arguments of most secularists against the interpretations of Islamists are also derived from Islam itself and are presented in a context affirming secularists' desire to declare themselves innocent of

99 Issa J. Boullata, Trends and Issues in Contemporary Arab Thought (New York: State University of New York Press, 1990), p. 156.

100 Abuæał , Contemporary Arab Thought, p. 121.

101 William E. Shepard, "Islam and Ideology: Towards a Typology," International Journal of Middle Eastern Studies, no. 19 (1987), p. 309.

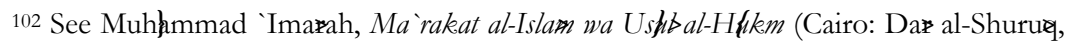
1989), pp. 170-1. 
an accusation that they know beforehand will be leveled against them."103

Another point deserves a careful examination is the relation between the secularist discourse and power. However, because of limited space, I will allude to this issue briefly. Indeed, the most striking difference between Indonesia and Egypt is the fact that there has been a long-held policy of Indonesian governments to provide ample opportunities for Muslim secularists to articulate their progressive ideas by restricting the religious agenda of the Islamists. In contrast, Egyptian governments have had antagonistic attitudes toward the secularist and Islamist groups. Throughout the history of postindependent Egypt, the regimes might overawe the Islamist movement and later destroy it. The Nasr regime once smashed the Muslim Brotherhood in the 1950s and 1960s, and later he wanted them to help him counter the Marxist left. Sadat did the same thing by reviving the Brotherhood, but later felt threatened so that he repressed them causing his assassination in 1981. President Husni Mubarak seems to deploy a clever tactic by allowing the moderates to take part in the Parliament while at the same time cracking down the radical Jiha $>$ wings.

As a result, as Geneive Abdo has demonstrated, in the last ten years the Islamist movement increasingly gained significant popularity not only in the grassroots, but also among professionals, business community, intellectuals, and other segments of the middle class. ${ }^{104} \mathrm{Of}$ course this situation strikes the liberals and secularists as dangerous and a step backward, away from the civil society they regard as the only way to progress. "Secularism in the Arab world is on the defensive in every sphere," screams Zakaria. The Islamists are now unhampered to the extent that they can threaten their opponents and bring them to the court to be officially declared as apostates. The case of Abu>Zayd can perfectly illustrate this situation. Therefore, the secularist voices are increasingly unheard. ${ }^{105}$

103 Zakaria, Myth and Reality, p. 21.

104 Abdo, No God but God, p.7.

105 For a detailed discussion on Abu $>$ Zayd's case, see Fauzi M. Najjar, "Islamic Fundamentalism and the Intellectuals: The Case of Nasr Hamid Abu Zayd," British Journal of Middle Eastern Studies, vol. 27, no. 2 (November 2000), pp. 177-200. 
In Indonesia, the success of the Islamic reform movement cannot be imagined without the socio-political environment, including the regimes' accommodative policy, which is conducive for such a movement to grow. Since the Sukarno regime, the first President of Indonesia, the Islamic political parties' activities were restricted. In 1960, the largest Islamic party Masyumi was banned and its leaders were arrested. During the Suharto regime, the relation between the regime and the Islamist groups did not improve, and he allowed only three political parties to compete in the general election none of which can be based on religion. He used repressive measures to exterminate any Islamic movement which he considered a threat to his government. As a result of these discouraging circumstances, coupled with the Suharto regime's determination to establish political order and stability at the expense of popular participation, it is fair to say that political Islam has been to large extent marginalized. ${ }^{106}$

I would argue that Sukarno's and Suharto's repression of political Islam between 1955 and 1998 -and the response of Muslim politicians and intellectuals to that repression- produced a sea change in Muslim political culture. In addition, we simply cannot ignore the fact that the regimes' support for the new Islamic intellectualism directly or indirectly makes it possible for this movement to flourish and influence the political Islam tendency towards moderation. The fact that Madjid was appointed as a member of Advisory Board of the Indonesian National Youth Committee (KNPI) -as the youth wing of the ruling party- in 1974, was an indication of government's support for the actor and initiator of the Islamic reform movement. ${ }^{107}$ Perhaps, this phenomenon can be said as a starting point for the involvement of young Muslim intellectuals in the national political arena. And this eventually brought about a new wave of relationship between Islam and the state in which Muslims became increasingly integrated into the process of development and modernization.

\section{Conclusion}

The debate on Islam and secularism has currently intensified as many Muslim majority countries confront an internal as well as external pressure demanding freedom and democracy. Judging

\footnotetext{
106 Effendy, Islam and the State, p. 114.

107 Ali and Effendy, Merambah Jalan Baru, p. 134.
} 
secularism as an illicit does not occur in Egypt only, but also in Indonesia. In July 2005, a government-sponsored "Council of Indonesian Ulama (Majelis Ulama Indonesia, known as MUI) issued a fatwa > banning "secularism", "liberalism", and "pluralism."108 Unfortunately, in both Indonesia and Egypt, the fatwas $>$ on secularism revolve around the problem of the terminology by identifying secularism with anti-religious movement. The whole trend of their argument is based on their assertion that if one believes in God, one cannot believe in secularism; that if one believes that religion is basis of one's life then one can have nothing to do with secularism. In short, secularism has come to mean atheism.

Of course it is too simplistic. They ignore the very fact that the concept of secularism has changed over times, and even in the West the discussion on secularism and secularization is far from being over. One Muslim author says that the concept of secularism has grown from its original concept of being anti-religion to a concept where respect for all religions is advanced and where discrimination on the basis of religion is not allowed to be practiced by a state. "On that basis," he says, "Islam to my mind is fully compatible with secularism." 109

It is clear that those Muslims who oppose secularism, as I discussed earlier, view secularization and secularism in very unsophisticated nature, for they rely above all on the dictionary meanings of "secular" and "secularism", which are invariably defined as "rejection of religion", or "a system of doctrines and practices that disregards or rejects any form of religious faith and worship." I would argue that this is no longer the concept of secularism, which already radically changed in the last hundred years. Surprisingly, none of the standard dictionaries have taken note of the changes in the concept of secularism since its first conceived. ${ }^{110}$ If we accept these definitions

\footnotetext{
108 This fatwa $¥$ as issued by MUI in its "National Convention" in Jakarta, on July 2629, 2005.

${ }^{109}$ Rafiq Zakaria, Is Islam Secular? (Aligarh: Aligarh Muslim University Press, 1989), p. 22.

110 Even the new editions of some well-known dictionaries do not take into account these changes. See, for instance, some dictionaries' definition of secularism: "a system of doctrines and practices that disregards or rejects any form of religious faith and worship" in Webster's New World College Dictionary (New York: MacMillan, 3rd edition, 1988); "a system of social organization that keeps out all forms of religion", in Longman
} 
then only communist states can qualify as truly secular. The two Muslim scholars discussed above have invited us to talk about secularism and secularization beyond the dictionary meanings. To them, it is not a heresy at all to insert a new (contextualized) meaning to the term or even to make it as a catalyst to discuss more crucial issues facing the Muslim world today.[]

\section{Bibliography}

Abdo, Geneive. No God but God: Egypt and the Triumph of Islam. Oxford and New York: Oxford University Press, 2000.

Abu $¥$ a) Ibrałrat. Contemporary Arab Thought: Studies in Post-1967 Arab Intellectual History. London and Virginia: Pluto Press, 2004.

Ali, Fachry, Bahtiar Effendy, and Ichsan Ali-Fauzi. "Nurcholish Madjid, for Islam and Indonesia." The Jakarta Post, August 30, 2005.

Ali, Fachry and Bahtiar Effendy. Merambah Jalan Baru Islam: Rekonstruksi Pemikiran Islam Orde Baru. Bandung, Mizan, 1986.

al-Qara Ilmi $>$ ala $¥$ Foud Zakaria wa Jama al-Tlmam Cairo: DapalS\{htyah, 1978.

Ananda, Endang Basri (ed). 70 Tabun Prof. Dr. Rasyidi. Jakarta: Harian Pelita, 1985.

Anwar, M. Syafi'i. Pemikiran dan Aksi Islam Indonesia: Sebuah Kajian Politik tentang Cendekiawan Muslim Orde Baru. Jakarta: Paramadina, 1995.

Bellah, Robert N. "Islamic Traditions and the Problems of Modernization," in Beyond Belief: Essays on Religion in a PostTraditionalist World. Berkeley and Los Angeles: University of California Press, 1991.

-------. Beyond Belief. New York: Harper \& Row Publishers, 1970.

Dictionary of Contemporary English (Britain: Longman Dictionaries, $3^{\text {rd }}$ edition, 1995); "indifference to or rejection or exclusion of religion and religious considerations", in Merriam-Webster's Collegiate Dictionary (Massachusetts: Merriam-Webster, Inc., 10 ${ }^{\text {th }}$ edition, 1993). 
Berger, Peter L. Against the World for the World: The Hartford Appeal and the Future of American Religion. New York: Seabury Press, 1976.

Binder, Leonard. Islamic Liberalism. Chicago: University of Chicago Press, 1988.

Boullata, Issa J. Trends and Issues in Contemporary Arab Thought. New York: State University of New York Press, 1990.

Callahan, Daniel (ed.). The Secular City Debate. New York: The MacMillan Company, 1966.

Cox, Harvey. Religion in the Secular City: Toward a Postmodern Theology. New York: Simon and Schuster, 1984.

--------. The Secular City. New York: The MacMillan Company, 1965.

Djaelani, Abdul Qadir. Menelusuri Kekeliruan Pembaharuan Pemikiran Islam Nurcholish Madjid. Bandung: Yadia, 1994.

Effendy, Bahtiar. Islam and the State in Indonesia. Singapore: Institute of Southeast Asian Studies, 2003.

Flores, Alexander. "Egypt: A New Secularism?” Middle East Report, No. 153 (July-August 1988).

--------.. "Secularism, Integralism and Political Islam: The Egyptian Debate." Middle east Report (July-August 1993).

Gallagher, Nancy E. "Islam Vs. Secularism in Cairo: An Account of the Dar al-Hikma Debate." Middle East Studies. 25/2 (April 1989). pp. 108-215.

Gellner, Ernest. Postmodernism, Reason and Religion. London: Routledge, 1992.

Hassan, Muhammad Kamal. Muslim Intellectual Responses to "New Order" Modernization in Indonesia. Kuala Lumpur: Dewan Bahasa dan Pustaka Kementrian Pelajaran Malaysia, 1982.

Hefner, Robert W. Civil Islam: Muslims and Democratization in Indonesia. Princeton and Oxford: Princeton University Press, 2000.

'Imarah, Muhłmmad. Al-'Ima wa Nabdqruna al-Hadi ah. Cairo: Daßal-Shuruæ, 1987.

-. Ma rakat al-Isla wa Usił>al-Ha\{km. Cairo: Dapal-Shuruథ, 1989. 
Longman Dictionary of Contemporary English. Britain: Longman Dictionaries, 3rd edition, 1995.

Lyon, David. "Rethinking Secularization: Retrospect and Prospect." Review of Religious Research, 26/3 (March 1985). pp. 228-43.

Mabruß, Muhłmmad Ibrałim. Al-Ilma al-Nashr al-Islaæriparh, 1990.

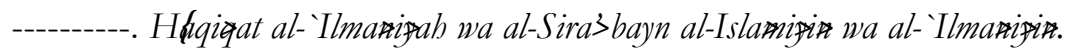
Vol. 2. Cairo: Daßal-Tawzi $\succ_{w a}$ al-Nashr al-Islamiæah, 2000.

Madjid, Nurcholish. "Sekularisasi Ditinjau Kembali," in Islam, Kemodernan, dan Keindonesiaan. Bandung: Mizan, 1987. pp. 257-60.

-. "Beberapa Catatan sekitar Masalah Pembaruan Pemikiran dalam Islam," in Islam, Kemodernan, dan Keindonesiaan. Bandung, Mizan, 1987. pp. 215-20.

- Islam, Kemodernan, dan Keindonesiaan. Bandung: Mizan, 1987.

-. Cita-cita Politik Islam Era Reformasi. Jakarta: Paramadina, 1999.

-------. Dialog Keterbukaan: Artikulasi Nilai Islam dalam Wacana Sosial Politik Kontemporer. Jakarta: Paramadina, 1998.

-------. Islam Agama Kemanusiaan. Jakarta: Yayasan Wakaf Paramadina, 1995.

--------. Islam Agama Peradaban. Jakarta: Paramadina, 1995.

-. Pintu-pintu menuju Tuhan. Jakarta: Paramadina, 1994.

------. Islam, Kerakyatan, dan Keindonesiaan. Bandung: Mizan, 1993.

-------. Islam: Doktrin dan Peradaban. Jakarta: Paramadina, 1992.

Merriam-Webster's Collegiate Dictionary. Massachusetts: Merriam-Webster, Inc., 10 $10^{\text {th }}$ edition, 1993.

Mulder, D.C. "Secularization in the Muslim World," in D.C. Mulder (ed.). Secularization in Global Perspective. Amsterdam: VU Boekhandel, 1981.

Najjar, Fauzi M. "Islamic Fundamentalism and the Intellectuals: The Case of Nasr Hamid Abu Zayd." British Journal of Middle Eastern Studies, Vol. 27, No. 2 (November 2000). pp. 177-200.

-------. "The Debate on Islam and Secularism in Egypt." Arab Studies Quarterly, 18/2 (1996). 
Pardoyo. Sekularisasi dalam Polemik. Jakarta: Pustaka Utama Grafiti, 1993.

Parsons, Talcott, Edward Shils, Kaspar D. Naegelle, and Jesse R. Pitts (eds). Theories of Society: Foundations of Modern Sociological Theory. New York: Free Press, 1961.

Rubin, Barry. Islamic Fundamentalism in Egyptian Politics. New York: Palgrave MacMillan, 1990.

Shepard, William E. "Islam and Ideology: Towards a Typology." International Journal of Middle Eastern Studies, No. 19 (1987).

Steenbrink, Karel. "Nurcholish Madjid and Inclusive Islamic Faith in Indonesia," in Ge Speelman, Jan van Lin and Dick Mulder (eds). Muslims and Christians in Europe: Breaking New Ground. Uigeverif Kok - Kampen, 1993. pp. 28-43.

Tamimi, Azzam. "The Origins of Arab Secularism," in John L. Esposito and Azzam Tamimi (eds). Islam and Secularism in the Middle East. New York: New York University Press, 2000. pp. 13-28.

van Leeuwen, A. Th. Christianity in World History. Edinburgh: University of Edinburgh Press, 1964.

Webster's New World College Dictionary. New York: MacMillan, 3 ${ }^{\text {rd }}$ edition, 1988.

Yared, Nazik Saba. Secularism and the Arab World (1850-1939). London: Saqi Books, 2002.

Zakaria, Fouad. Al-Háqiqah wa al-Khayasizal-Hárakah al-Islamizah alMu a 7 ah. Cairo: Sita>1988.

-------. Al-Sáhyah al-Islamizh fi 1989.

. Myth and Reality in the Contemporary Islamist Movement. London and Ann Arbor: Pluto Press, 2005.

-----. Nietzsche: Silsilah Nawa) al-Fikr al-Gharbi. Eairo: DapalMa årif, 1956.

-------. Spinoza. Cairo: Daßal-Nahdłh al-`Arabipah, 1963.

------. Ar $>$ Naqlizeth fi $\gg$ Mushkilat al-Fiker wa al-Thaqafh. Cairo: alHay’ah al-'A mah li al-Kita\$, 1975. 
. Al-Tafkiral-'Ilmi. Xuwait: Silsilah `Alm al-Ma’rifah, 1978.

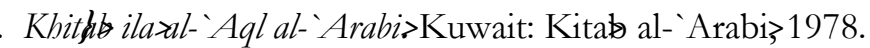

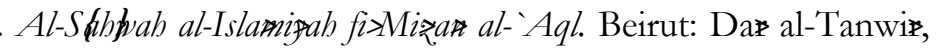
1989.

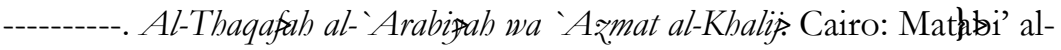
Ahram, 1991.

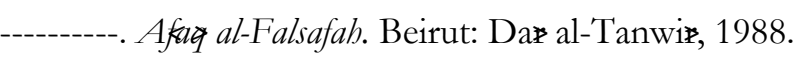

Zakaria, Rafiq. Is Islam Secular?. Aligarh: Aligarh Muslim University Press, 1989. 